\title{
Impact of Total Quality Management on Customer Satisfaction (E-Services)
}

\author{
RAYA MUSLIM SADIK \\ Business and Information Technology Lecturer. \\ Master of Mechatronics Engineering, University of Technology, Baghdad- Iraq rayasadik@ gmail.com
}

\begin{abstract}
Total quality management is a management system that is based on that every person who is working in the organization should be committed to achieve organization goals and meet company's high standards. The main aim of organization is customer satisfaction. Quality management is the basic tool that leads to quality assurance and will ultimately result in customer satisfaction.

The total quality management is the part of the business in modern age. Everyone use it and in eservices, it has more importance because most of the services are virtual i.e. performed using the tools of information technology.

When we talk about quality, it means that the product of service, which we are making or offering to the consumer or users, should be fit for the purpose, free from errors and mistakes, fit for the use and meets the need of the customer.

In addition to the above the quality in e-business is crucial as it involves the three important dimensions i.e. quality management, quality control and quality assurance. In order the manage, control and assure quality in the e-services environment the avoidance of conformance costs i.e. detection and prevention costs and non-conformance costs i.e. internal failure and external failure costs are essential.

The implementation of Total Quality Management (TQM) in e-services environment includes the empowerment of team, systematic problem solving, data derivers' decision, statistical process and selection and use of appropriate problem solving tools and techniques.

The organizations who are able to perform the above in their e-services can do the fast communication, implementation and decision-making and achieve the simplicity and flexibility in their processes. In this way, they are not only able to get the faster response from their customers but they can provide better satisfaction to their customer, which is essential for their growth and development and to achieve their financial and non-financial objectives effectively and efficiently.
\end{abstract}

\section{KEYWORDS}

Total quality management - Customer focused customer satisfaction - electronic service sustainable environment - better productivity managerial improvement - operational management.

\section{INTRODUCTION}

Total quality management is the operational management that is used by a firm for better work and their ultimate aim is customer satisfaction. As we all know, in this competitive world, a firm wants to go for something that will help them in sustaining them in this competitive market. Every organization wants to aim for the best and a good company focuses on the customer satisfaction because they are the main output. To gain competitive advantage, a firm has to go for quality management in their firm.

There are three quality assurance tools such as quality planning, quality improvement and quality improvement. In quality planning, the target market has been recognized and started working on their mind set. The whole planning is done in this part of quality assurance. The second one is quality control in which the quality of current process is assessed and the last one is quality improvement in which the quality is improved. These three points are very important in quality assurance process.

Total quality management in the continuous improvement in organizational processes that makes an organization different from other. Product or service of a company should be assured and total quality management is used for project and product assurance and control. This will result in organizational improvement, managerial efficiency, and effective management and with that continuous improving productivity. The company who has implemented total quality management in their firm would be customer focused and they would definitely know the demand of their buyers. There are 7 basic tools that are used in total quality management such as check sheet, histogram, cause and effect diagram, control chart, Scatter diagram, flow chart and last Pareto chart. [1,2] 
Total quality management also makes aware of the changes that are taking place in the surrounding environment and information related to updating the product. Whereas, electronic service (e-service) is the use of information and communication technologies (ICTs) in different areas. The main role of e-service is to facilitate the customers with the service by information technology. They have three main components such as the service provider (who provides the service e.g. delivery boy), the second one is service receiver (the one who receives the service e.g. the customers) and the last one is the channels through which a customer gets the service (e.g. application, technology). The best examples of e-service can be delivery service and customer support.

In general, if a company implements total quality management in their respective fields, this will improve in internal quality impact of customer satisfaction and the business will grow ultimately. Customer satisfaction is an output and if the business results in better output. It will also result in organization's customer orientation.

One of the example of implementation or impact of total quality management on customer satisfaction is e-service which is very much used by the government of many countries, named as e-government. Egovernment is the use of information technology or application for the betterment of the state and providing services to the people of the state. The main aim of e-government is to satisfy their citizens, increase the efficiency and more citizen involvement with the government. USA government has designed applications for the citizen of America through which the people can more participate with the government activates. This application is used in many ways such as, they can find information about the retirement plans and labor laws, they have the information about loans, taxes, and welfare, they can also learn about the citizenship, passports, and visa and can get to know and also participate in all type of government issues.

\section{EXAMPLES of TQM and E-SERVICE}

Uber and UberEATS is one example of electronic service. For Uber, all you have to do is call and book a car ride through Uber app and it will at your doorsteps in 7-10 mins. UberEATS is a derived version of Uber. It's application found in Uber app which is used to order food from the nearest restaurants. These are a good example of total quality management through e-service and resulting in customer satisfaction. Uber and UberEATS is a quality management which helps their customers by giving a service. The quality of Uber is assured by this quality management and this is resulting in better customer loyalty and satisfaction. This is one reason that Uber is growing and growing.

Another example of e-service can be the portal in many universities and e government portal. These portals are used to sign up and be engaged with the happenings in university or in the state. This is a perfect example of total quality management. Portals are used to assure the quality of the organization and government and if the quality is being assured, the customers will be fully satisfied. Portals are for the ease of the customers. The customers use portal and they have each and everything they want to know or go through on portals which is again resulting in customer's satisfaction and improvement of services.

\section{RESEARCH QUESTIONS}

The research will be based on these questions:

1) How is total quality management used to assure the customer satisfaction?

2) How is e-service used for the assurance of quality management?

3) How has e-service made life easier for a normal person?

\section{LITERATURE REVIEW}

As the competition is increasing in the market, every firm wants them to be different from others to have the competitive edge. Total quality management is continuous improvement in an organization where all the employees are equally and actively participating in it and their aim is to increase the customer satisfaction. Total quality management has 8 principles which are very important for a company to implement a quality management [1,2]. Customer focus is the most important principle in TQM. A firm that would be customer focused would know that a customer is the one who determines the level of quality and quality in an organization will make a customer loyal. For example, McDonalds assures that the food is properly cooked and cooked in given time period. Customer satisfaction is their utmost goal and they are achieving and maintaining their standards in every country. That is one reason that McDonalds is always full of people because they give quality food and they are nothing without their customers. The second principle of TQM is the total employee involvement. Every employee who is working in an organization should be actively engaged in company's continuous improvement because this will lead to customer satisfaction. For example, the employees working in McDonalds cover their head and hands for the quality assurance and quality control and to assure the hygiene. And employees 
work in a group which shows teamwork. This will also lead in organization's improvement and customer satisfaction.

The third principle of total quality management is process centered. Process-centered is a performance that is continuously measured to suspect unexpected variation. For example, there is a team to assure the food quality and cleanliness in McDonalds which keep a check on the input, process and output. The organization which is process centered also results in customer satisfaction. The fourth principle of TQM is an integrated system. For example, in McDonald's they have different team assigned to carry out processes such as there is a team for cooking, for serving and for customer dealing but they all are integrated as one system and their goal is to satisfy their customers because they are main output. The fifth principle is the strategic and systematic approach. This principle is all about that the quality management of an organization and the approach should be systematic and strategic because this will help in achieving the mission and goals of the organization. For example, McDonalds has a systematic and strategic approach because they have a system to be followed and a strategic approach to every decision in the organization. This is one way that will assure that a customer is very much impressed by the organization that has a certain system to follow. The sixth principle of total quality management is continual improvement. It is the base of TQM. The performance of the firm should be improved from better to good and good to best. For example, McDonald's special team supervises the employees for better performance and continuous improvement and this is the reason many customers trust on them. The seventh principle is decision making. The decision making of the organization should be fact-based and they should gather the facts from an authentic source. For example, In McDonald's or in any organization if new decision is taken they are based on facts. The last principle is communications. Effective communication plays a great role in customer relationships as well as employee motivation. These all principles help an organization to gain competitive advantage, improving productivity and customer satisfaction. For example, there is no communication gap between the employees in the organization. They should be friendly with one another. McDonalds have a very kind and friendly employee behavior with one another. It is the reason they work together as one team and it is resulting in good brand name, customer satisfaction, customer loyalty and making profits.

According to an article by G. S. Kim (2016), the most successful organizations have found that the fundamental principles of total quality are essential to effective management practice, and continue to represent a sound approach for achieving business success. Total Quality Management (TQM) is the business world's leading management method and companies employ use this method to improve their productivity and service quality with the hopes of improving typical measures of business performance (e.g. increased profits, increased market share, reduced costs). Excellent quality is regarded by most producers as one of the most important aspects of manufacturing, service and buyer's strategies.[3]

Basically, it focuses on three points that are quality leadership, customer focus, and process management. The company who focuses on these three points will have a quality management.

As the online market is rapidly growing, many companies have started using e-service. According to an article by Y.H. Wang and W.Y. Yang (2009),eservice has the interrelationship among the perception of e-service quality, customer satisfaction, and customer loyalty. E-service quality has an influence on customer satisfaction and then generates customer loyalty. A customer will have a good brand or corporate image and secondly, according to Gucci Family Slogan, "Quality is remembered long after the price is forgotten." [4]

E-service is an electronic service through information technology or application for creating an ease in customers life. E-service implies quality tools for the quality assurance, better productivity and making profits and revenue, sustaining a competitive edge. Eservice is electronic service through information technology. It has a quality impact on the customers because customers want ease in their life and organization having e-service assures that the customers are fully satisfied with them.

An application such as Uber, UberEATS, food panda, Talabat, and Amazon are the examples of the eservice.

Service is frequently used by the government that has been named as e-government. E-government has implemented quality tools for helping their citizens. It is a kind of creativity and innovation which is very much influenced by citizen and their behaviors, their information needs and how people will work and communicate with the government. This electronic service brings ability to access variety of information for the local people, new and innovative way of interacting and it supports the knowledge sharing with them. It is also for the assurance of quality which is the utmost important thing of all. According to an article by A.T. Bon and M.A. Mustafa, quality is excellent; quality is the value; quality is conformance to specifications, and quality is meeting or exceeding customers' expectations. According to another article by G. S. Kim (2016), he says quality 
management is positively related to employee engagement, customer satisfaction, and continuous improvement. Therefore, the crux of it is that total quality management has a great impact on customer satisfaction because quality management will assure the quality and the customers will always go for quality. This will result in customer loyalty and customer satisfaction. [5, 3]

\section{FUTURE OF TQM IN CUSTOMER SATISFACTION FIELD}

Implementation of total quality management will change the market and organizations in future. It will help in achieving organizational goals. It will also help the customers to achieve customer satisfaction and understanding. There will be management commitment of the employees with the organization. If all the system of the organization work in a quality management and in a systematic way then this all will ultimately result in better customer and supplier relationship.

\section{METHODOLOGY}

I have done this research through 10 questionnaires. I have distributed them among 5 teachers of marketing and 5 students of marketing at University of Dubai. The reason for distributing this survey was to conduct a research and know that how much are people aware of the importance of quality management and how quality management will lead to better customer relations.

\section{PARTICIPANTS}

I have distributed these questionnaires to 10 people in University of Dubai. 5 were the teachers from business department, majors in marketing and 5 were the students. I wanted to check that how much they are aware of the importance of quality management in e-service and relationship of quality management with customers.

\section{RESULTS}

The topic of my research paper is "Impact of total quality management on customer satisfaction (eservice)". The distribution was among the teachers and students. The first question that I asked them was "are they aware of the e-service?". It was a question with the option of yes or no. 10 out of 10 people was aware of e-service and its benefits. Everyone choose yes for the answer. Figure 1Shows all person chooses yes for this question

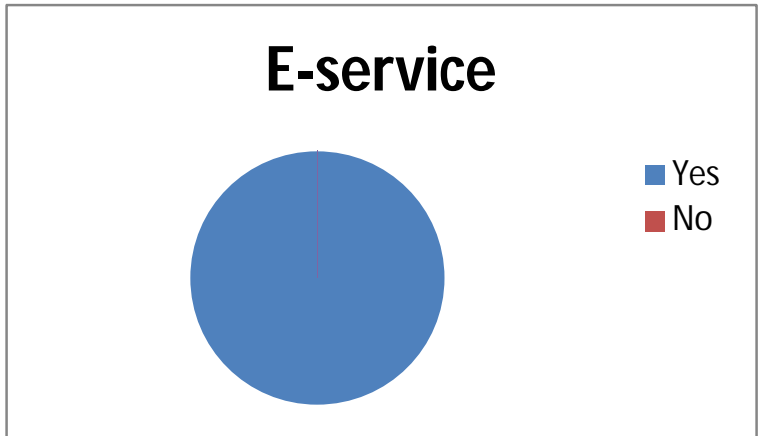

Figure (1) Participations Response to the First Question

The second question in my survey was "is e-service for the assurance of quality management?" This question had two options to choose the answer, yes or no?. As shown in Figure 2, eight out of ten people choose yes and two people choose. It means $80 \%$ of people think that e-service is for the assurance of quality and $20 \%$ of people think that it is not for the assurance of quality.

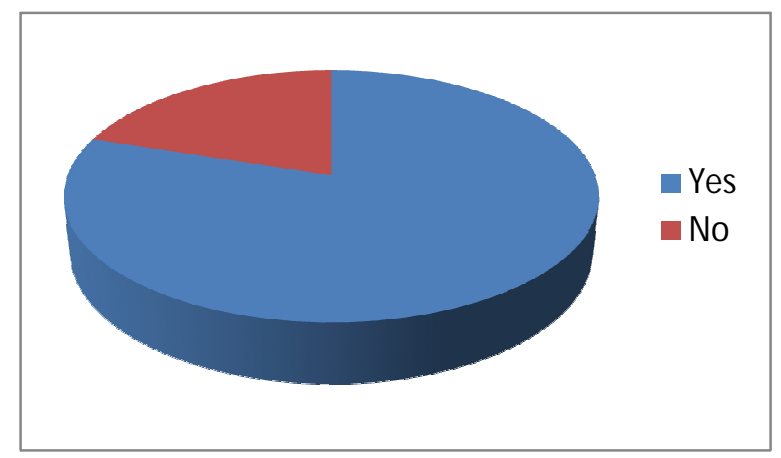

Figure (2) Participations Response to the Second Question

The third question in the survey was "will e-service result in customer satisfaction? How?" It was an open-ended question. There were different answers to this question. Seven out of ten people said yes it results in customer satisfaction because people in this era want to ease in their life. They want easily facilities. If an organization is working for the ease and facilitate their customer with e-serve then customer will be fully satisfied and customers are fully linked with the quality of e-service whereas three people voted for no and the reason they gave for no was like that there are so many people in the third world who are not into technology right now. It is not that easy for them to use technology or applications.

The fourth question the questionnaire survey was again an open-ended question. The question was "how is total quality management used to assure the customer satisfaction?" The common answer that got was this question was that total quality management includes quality control and quality assurance when all these things are combined the product or service 
made are of the best quality. The customer's best preference is the quality. They can spend more on good quality so total quality management assures quality and keeps the customers fully satisfied.

The fifth question in the survey was that "how is eservice used for the assurance of quality management? " The answer that I frequently got for this question was e-service is used to assure quality by taking feedback of customer by using electronic media such as applications etc. and keeping quality checks by using information systems.

The sixth question in research questionnaire was "how has e-service made life easier for a normal person?" As we all know that every single wants everything information whether it's related to news, sports, health or fashion, everything should be one click away. The answer that I constantly got for this question was that e-service has made life easier as nowadays life is being very busy and people don't have time to go out and find people to do their work like plumbers and technicians. Therefore, people are developing applications of e-services, which will provide each and everything to your doorsteps. Everything will be one click away whether its technician, plumber or cook.

The last question that I have asked in the survey was "what is the mission of e-government?" There were four choices for this question. First, was enhancing efficiency, the second was an effective platform for opportunities, third was promote and support the government and last was all of the above. As shown in Figure 3, five people choose enhancing efficiency, two choose to promote and support government and three choose all of the above.

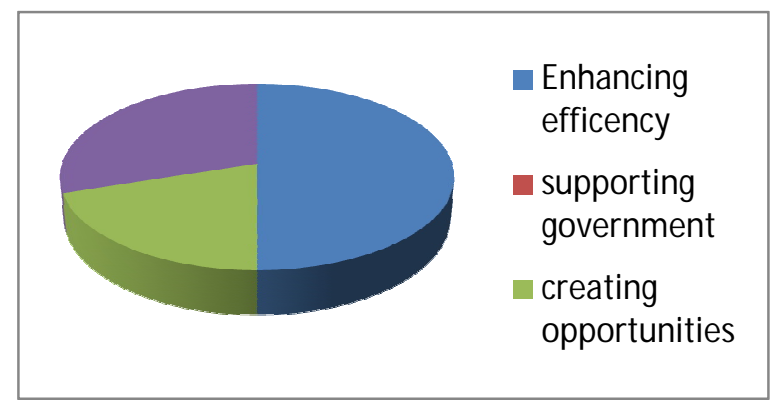

\section{Figure (3) Participations Response to the Last Question}

\section{CONCLUSION}

As we already discussed that high-quality, assurance and quality control will lead to quality management. In addition, total quality management of an organization will result in customer satisfaction. Eservice is quality management that is making people's life easier. If something result ease in customer's life, the customers will be loyal to that organization and they will be fully satisfied. Therefore, E-service is like an input that is procsessed with quality management and the output will be the customer satisfaction.

\section{REFERENCES}

[1]http://asq.org/learn-about-quality/total-qualitymanagement/overview/overview.html

[2]Jay Heizer, Barry Rnder, Chuck Munson. (2017). Operation management: Sustainability and Supply Chain Management. Part2 (chapter 6). Twelfth Edition

[3]Kim, G.S. (2016). Effect of total quality management on customer satisfaction .International Journal of Engineering Sciences\& Research Technology, 5(6), 507-514. (Literature review page13)

[4]Chang, H. H., Wang, Y. H., \& Yang, W. Y. (2009).The impact of e-service quality, customer satisfaction and loyalty on e-marketing: Moderating effect of perceived value. Total Quality Management, 20(4), 423-443. (Literature review, page 13) https://doi.org/10.1080/14783360902781923

[5]Bon, A. T., \& Mustafa, E. M. (2013). Impact of total quality management on innovation in service organizations: Literature review and new conceptual framework. Procedia Engineering, 53, 516-529. (Literature review, page 9) https://doi.org/10.1016/j.proeng.2013.02.067

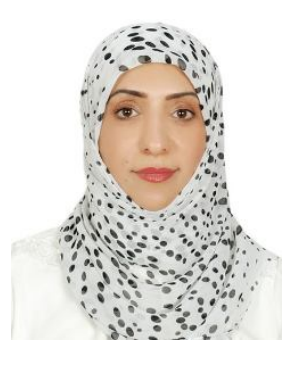

Raya Muslim Sadik received the M.S.C in Mechatronics Engineering at University of Technology, in( 2000)- BaghdadIraq, she has been teaching Business and Information Technology courses since 2001; She is interested in the following Fields (Total Quality of Management ,Knowledge Management, Management information system 